\title{
The Intervention and Application of Inquiry Learning in the Design History Teaching of Art Design Specialty
}

\author{
Dapeng Zhou \\ Guangdong Industry Technical College \\ Guangzhou, China
}

\begin{abstract}
The teaching of art design history course has confronted with a host of problems and difficulties. Through analyzing problems in teaching process, it is put forward that from upgrading teaching methods, reforming teaching materials, improving examination method and other aspects, use the teaching methods of inquiry learning to explore a teaching mode which adapts to the development of times.
\end{abstract}

Keywords-art design; design history; teaching; inquiry learning

\section{INTRODUCTION}

As a professional basic theory course required for students of art design specialty, design history is aimed at making students learn and master the evolution process of art design trend and basic theory of design creation, as well as gradually enhancing the ability of aesthetic appreciation, thinking in images and art design originality, so that the future art design creative activities are laid a solid foundation of comprehensive quality and theory. The traditional design history teaching is a one-way teaching mode which centers on teacher, class and book. And classroom teaching of teachers is mainly the single instruction-centered teaching mode, which one teacher teaches many students at the same time. Due to the only emphasis on teachers' effect in the teaching process and neglecting students' initiative learning process, this kind of teaching mode has existed severe disadvantages. Under the instruction-centered teaching mode, students uncritically accept teachers' directly delivered knowledge without thorough understanding, which easily leads to a dull and depressing classroom teaching atmosphere. And students feel boring and drowsy, thus the teaching quality is never high. With innovative thinking ability increasingly taking up the dominant position in teaching ability cultivation and the occurring of various problems, it is indicated that traditional single instruction-centered teaching mode must be reformed. New teaching method must center on students, and launch attention to inspire students' consciousness and independence and to develop students' creative learning ability. From the practice of curriculum reform in world's major countries, curriculum structure has shifted from only emphasizing content teaching to focusing on the combination of content teaching and ability exercise, which better ensures students to acquire theory knowledge with a high efficiency and to concurrently master skills and creative ability. Inquiry learning is no other than a brand-new curriculum structure and learning mode which is emerged from the course of curriculum reform.

\section{OVERVIEW OF INQUIRY LEARNING}

Inquiry learning is an active learning process, and lays emphasis on the process. It mainly denotes the learning mode which students inquire problems in teacher's teaching. In its implementation, the method of step-by-step implementation should be used. Firstly, teachers create some problems for students and assign the research task. Secondly, after confirming the problem to be researched and solved, students enter to the actual problem-solving process, forming certain concepts and attitudes and mastering certain method through practice and experience. Lastly, with entering to the expression and communication stage, students should classify and conclude the results of self or team's practice and experience, then form written or oral report materials. It should be noted that the way of expressing results should be diversified. Besides writing research report according to some requirements, results can be published through debate, seminar and other ways. In the learning process, students initiatively participate in the controlling of the whole teaching process. Through looking up and using the relevant information and materials in learning resources, students can acquire the ability of identifying, collecting, processing, handling, utilizing and evaluating information. Students take up the main body and leading position in the whole learning process. The goal of applying inquiry learning to design teaching is a follows: cultivate students' initiative and learning curiosity; maximize students' open thinking ability and initiative exploration spirit; train students' ability of acquiring information from various channels; improve students' communication and expression ability; make students initially master law and method of scientific research and exploration; cultivate students' cooperation consciousness and participation spirit; improve students' independent activity ability. These goals precisely consist with goals of cultivating designer's professional quality.

\section{APPLICATION OF INQUIRY LEARNING TO DESIGN HISTORY TEACHING}

In the application of inquiry learning to design history teaching, special subject teaching should be used as the 
framework to connect the whole curriculum system, problembased learning should be used as the important procedure of curriculum, and lastly supplement the corresponding assessment method. These three together build an educational framework for the teaching of design history, giving the full play of students' initiative, and changing the one-core teaching mode which centers on teacher to the two-core teaching mode which centers on students and is supplemented by teachers.

\section{A. Special Subject Teaching}

The compilation of history design content mostly uses time as the longitude and design content categories as the latitude. With a weak link between contents in the front and in the back, this two-dimension teaching structure can easily decompose knowledge. The history of art design is developed according to the evolution of time and has a more obvious order and regularity. Therefore, teaching is displayed according to this order: divide design style according to time, arrange class hour and times according to the chapters of each style, and teach the design style from past to now and the future design trend. This illustrates that only curriculum is planned to design from the macro can ensure the orderliness and completeness of teaching content. Then students can gradually master the context and law of design history. Otherwise, their learning interest and mood will be demoralized when they are unable to learn in face of the vast amount of information and knowledge. Special subject teaching is closely linked to the teaching goal, and breaks the original structure mode namely taking teaching materials as the key link. It divides the teaching content into a number of interrelated and relatively independent subjects, then teach around each subject namely combine divergent thinking method to teach in the linear thinking teaching process. Due to the influence of mainstream design style in a certain period, there still have some non-mainstream stylee or the co-existing of some kinds of popular styles. This is to say that art design history itself has complex features in its horizontal development. Thus, although it is difficult to cover all in the limited time, the explanation of other styles can be radiated from the teaching of one style under some permitted condition. In this way, students can better compare the differences between different design styles. For this purpose, the content of design history can be divided into history of architectural design, history of landscape design, history of furniture design, history of ceramic design, history of textile and apparel design, history of advertising design, history of industrial product design, history of poster design and other subjects. Then with each subject as the center, explore the historical evolution of each art design category from sociology, philosophy, aesthetics, psychology, design ontology and other aspects. The content of design history can also be divided into functionalism, minimalism, art deco, eclecticism, postmodernism and other subjects according to differing design thoughts and aesthetic pursuit. Then analyze these differing design thoughts, esthetic features and ideological connotation by combining these subjects with art design masters and their representative works. Breaking the rigid mode of traditional curriculum teaching, special subject teaching helps clarify the teaching goal of design history curriculum to strengthen students' learning target, and also deepens students' learning about design history to better play basic theory's guiding role in design creation.

\section{B. Problem-based Learning}

Problem-based learning is to put forward questions centering on the teaching important and difficult points of design history. It makes students themselves seek and explore the solutions of these problems, and then teachers make the comment explanation. In the teaching process, students should be encouraged to dare to question and challenge the authority and cultivated the ability of finding problems. Because if there is no problems in learning, not mention the meaningful learning. Problem-based learning can improve students' divergent thinking ability and creative thinking ability. Use flexible and differing teaching methods to improve students' learning initiative and change students from passive learning to active learning. The traditional teaching site of design history is the classroom, and the teaching method is centering on teachers' instruction, thus students lacks participation, which leads to their low learning activeness to some extent. Problembased learning can organically combine with heuristic education, paying attention to create problem situation to enlighten students' thinking and cultivate their creative ability. Use interactive dialogue mode when do the one-core teaching to start the dialogue between teachers and students, to know students' thoughts, to lead their learning and to inspire their independent thinking. Teachers or students should put forward questions and let students independently think and explore solutions. When students encounter problems that cannot addressed by themselves, teachers should just coach them, serving the function as guiding and promoting. Arrange more interactive discussion in a way of teachers and students equally participating and co-discussing. Fully open group discussion can be adopted, and each group should develop the problems that they need and care about. Here, teachers mainly provide developing ways and methods to guide students, while the discussion content an process should be completed by students After applying inquiry learning to design history teaching, teaching forms will be more open and free. For instance, arrange students to visit museum, explain the design works, and let students copy some important form and sketch them on the spot, which strengthens their memory and understanding on one hand, and trains their hands-on ability.

\section{Assessment Method}

Reform the traditional examination method and cultivate students' creative ability. The traditional examination method of design history is to carry out a one-time closed test after finishing the courses. This kind of examination has serious drawbacks, which is in conflict with the cultivation goal of design talents. The test content by rote and standard answers cannot assess the true level of students, and seriously restrict the cultivation of students' creative spirit and innovative ability as well. Based on the cultivation goal of creative talents education, students' daily learning process can be strengthened to be more in line with the requirements of quality education. Examination methods can use closed test, open test, question answering, paper writing, and method combining with open reply. Comprehensive assessment on students' knowledge 
application ability and innovative ability can be achieved, so as to effectively realize the goal of new education.

\section{CONCLUSION}

As a learning way, inquiry learning focuses on the ability of students themselves to explore problems and solve problems; as a teaching method, it breaks the emphasizing-knowledgelogic characteristic of traditional design history teaching. However, as a brand-new curriculum teaching philosophy, the implementation of inquiry learning in design history teaching is a completely new work.

\section{REFERENCES}

[1] Li Gongming. Concept, Narrative Method and Problem-Consciousness in the Textbooks of Art History [J]. Art Research, 2001. 1.

[2] Lü Feng. History of Art Design [M]. Shenyang: Liaoning Fine Arts Publishing House. 2006.

[3] Yang Yong. Cultivation of Inquiry Learning and Students' Ability Based on Resources. Research of Current Basic Teaching. 2002.7-8.

[4] Elementary Education Department of Education Ministry. The Guide of Implementing "Inquiry Learning" in Regular High School. Elementary Education [2001]. 